\title{
ОЦЕНКА УСЛОВИЙ ПИТАНИЯ, УРОЖАЙНОСТИ И КАЧЕСТВА КАРТОФЕЛЯ ПРИ ВНЕСЕНИИ НОВОГО ОРГАНО-МИНЕРАЛЬНОГО УДОБРЕНИЯ
}

\author{
O.A. Sorokina, M.V. Zimoglyad
}

\section{THE ASSESSMENT OF NUTRITION CONDITIONS, YIELD AND THE QUALITY OF POTATOES WHEN APPLYING A NEW ORGANIC AND MINERAL FERTILIZER}

Сорокина Ольга Анатольевна - д-р биол. наук, проф. каф. почвоведения и агрохимии Красноярского государственного аграрного университета, г. Красноярск. E-mail: geos0412@mail.ru Зимогляд Максим Викторович - асп. каф. почвоведения и агрохимии Красноярского государственного аграрного университета, г. Красноярск. E-mail: geos0412@mail.ru

Обобщены материалы многолетних полевых опытов по изучению эфрфрективности применения нового органо-минерального удобрения (ОМУ) местного производства под картофель сортов Адретта и Арамис. Проведена оценка действия этого удобрения при разных нормах и способах внесения на черноземе выщелоченном в условиях лесостепной зоны Назаровского района. Картофрель относится к культурам интенсивного типа питания, предъявляющим повышенные агроэкологические требования к условиям выращивания. Дана оценка этих условий в наиболее ответственную фазу вегетации, цветения картофеля, по комплексным показателям почвенного плодородия: содержанию общей влаги, реакции почвы, обеспеченности основными питательными элементами. Результаты почвенной диагностики показывают, что на удобренных вариантах, по сравнению с контролем, влажность почвы в пахотном и подпахотном слоях выше за счет влагоемкого торфа и вермикулита в составе ОМУ. На всех удобренных вариантах не зафиксировано существенное смещение реакции почвы по величинам актуальной и обменной кислотности, что дает возможность положительно оценить новое удобрение, в состав которого входят компоненты кислой природы. Оценка обеспеченности основными питательными веществами
Sorokina Olga Anatolyevna - Dr. Biol. Sci., Prof., Chair of Soil Science and Agrochemistry, Krasnoyarsk State Agrarian University, Krasnoyarsk.

E-mail: geos0412@mail.ru

Zimoglyad Maxim Victorovich - Post-Graduate Student, Chair of Soil Science and Agrochemistry, Krasnoyarsk State Agrarian University, Krasnoyarsk.

E-mail: geos0412@mail.ru

свидетельствует об оптимальных условиях питания картофреля при внесении ОМУ как по сумме минеральных форм азота (аммонийного и нитратного), так и по содержанию подвижного фоосфора и обменного калия. В оптимальные по погодным условиям годы исследований установлена более высокая эфрфективность ОМУ, получены достаточно высокие уровни урожайности картофреля обоих сортов. В засушливые годы невысокие уровни урожайности характерны для картофеля сорта Адретmа в 2016 г. и сорта Арамис в 2018 г. как на контрольном варианте, так и при внесении ОМУ. В эти годы при увеличении нормы внесения удобрения проявляется токсический эффект за счет повышенной концентрации почвенного раствора и отрицательного действия хлора, входящего в состав ОМУ. Максимальная эфффективность получена при внесении минимальной дозы нового органоминерального удобрения в период посадки клубней, а также во время подкормки при междурядной обработке, в зависимости от условий года. Клубни картофеля сорта Арамис по сравнению с сортом Адретта способны к более сильной кумуляции нитратов. По содержанию нитратов продукция картофреля обоих сортов во все годы исследований и на всех вариантах характеризуется как экологически безопасная. 
Ключевые слова: органо-минеральное удобрение, условия питания, эфффрективность, картофрель, сорт, варианты опыта, элементы питания, влажность, реакция почвы, урожайность, содержание нитратов.

The materials of long-term field experiments to study the effectiveness of the use of a new organic and mineral fertilizer (NOF) of local production for potatoes of Adretta and Aramis varieties were summarized. The assessment of the effect of this fertilizer at different rates and methods of application on leached Chernozem in the conditions of the foreststeppe zone of the Nazarovo district was carried out. Potatoes belong to intensive type of food crops having high agroecological requirements for growing conditions. The assessment of these conditions in the most important phase of vegetation, potato flowering, was given by complex indicators of soil fertility: the content of total moisture, soil reaction, and the availability of basic nutrients. The results of soil diagnostics showed that in fertilized variants, in comparison with the control, the soil moisture in arable and sub-arable layers had been higher due to the moisture-intensive peat and vermiculite in the composition of NOF. On all fertilized variants, a significant shift in the soil reaction in terms of actual and exchange acidity was not recorded, which makes it possible to evaluate positively the new fertilizer containing the components of acidic nature. The assessment of the availability of basic nutrients indicated the optimal conditions for potatoes nutrition when applying NOF, both in terms of the sum of mineral forms of nitrogen (ammonium and nitrate), and of the content of mobile phosphorus and exchangeable potassium. In the years of the research optimal for weather conditions, a higher efficiency of NOF was established, and sufficiently high levels of yield of potatoes of both varieties were obtained. In dry years, low yield levels were typical for potatoes of the variety Adretta in 2016 and the variety Aramis in 2018, both in the control variant and when introducing NOF. In these years, when the rate of fertilizer application increases, toxic effect was manifested due to the increased concentration of soil solution and the negative effect of chlorine, which is part of the NOF. The maximum efficiency was obtained by applying a minimum dose of a new organic and mineral fertilizer during the planting of tubers, as well as during fertilizing and row-to-row processing, depending on the conditions of the year. Potato tubers of the
Aramis variety in comparison with the Adretta variety are capable of a stronger accumulation of nitrates. According to the content of nitrates, potato products of both varieties are characterized as environmentally safe in all years of research and all variants.

Keywords: organic and mineral fertilizer, nutrition conditions, efficiency, potatoes, variety, experiment variants, nutrition elements, humidity, soil reaction, yield, nitrate content.

Введение. Сбалансированное многоэлементное питание растений и качество продукции предполагают использование целого комплекса макро- и микроэлементов [1, 2]. Использование даже умеренных доз удобрений (до 40 кг/га) способствует повышению адаптации растений к стрессовым факторам, более эфффективному использованию запасов почвенной влаги и осадков, стабилизирует во времени урожайность полевых культур на достаточно высоком уровне [3, 4].

В Красноярском крае уровень химизации пока остается низким, и при десриците минеральных удобрений очень важно применение местных удобрений на основе природного органического сырья, продуктов жизнедеятельности животного происхождения и отходов промышленности для получения высокой урожайности сельскохозяйственных культур [5]. Поэтому в последние годы большое значение в земледелии РФ и Красноярского края имеет замена дорогостоящих промышленных туков более дешевыми органоминеральными удобрениями (ОМУ), произведенными в местных условиях [6]. Органоминеральное удобрение (ОМУ), созданное ООО «ПИК» г. Красноярска, является одним из таких удобрений. Оно многоэлементное, пролонгированного действия, оптимизирующее питание растений, улучшающее физические свойства почвы за счет органического и минералогического компонентов. Органо-минеральные удобрения, как правило, рекомендуется применять под культуры интенсивного типа питания, такие как картофель и овощи $[1,7,8]$. В последние годы большое значение придается изучению биологически активных препаратов на основе гуминовых веществ, показывающих высокую эффрективность применения под картофель [9-11]. Научно обоснованные рекомендации по внесению этих удобрений в местных условиях не разработаны. Поэтому всестороннее изучение таких видов удобрений является актуальным. 
Цель исследования. Изучение эффрективности разных норм и способов внесения нового органо-минерального удобрения (ОМУ) на условия питания, урожайность и качество картофеля сортов Адретта и Арамис.

Объекты, методы и результаты исследования. Провели многолетние полевые опыты на черноземе выщелоченном Назаровского лесостепного природного округа. В 2015-2016 гг. изучили эффективность ОМУ при внесении под картофель сорта Адретта, в 2017-2019 гг. под картофель сорта Арамис.

Схема опыта была со следующими вариантами: неудобренный контроль, нормы внесения ОМУ 1 ц/га; 1,5 ц/га; 2 ц/га при посадке, норма внесения ОМУ 1 ц/га при междурядной обработке во время прополки и перед окучиванием. Повторность опыта трехкратная с систематическим размещением делянок площадью учета 10 м².

Для оценки условий питания картофеля на всех вариантах опыта в наиболее ответственную фазу вегетации, цветение, отбирался почвенный образец из слоев 0-20 и 20-40 см. Определили основные почвенно-агрохимические показатели: содержание общей влаги термовесовым методом, величины актуальной $\left(\mathrm{pH}_{2} \mathrm{O}\right)$ и

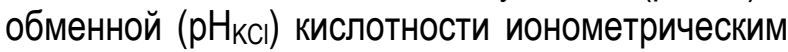
методом, количество питательных элементов (минеральные формы азота - аммонийный (N$\left.\mathrm{NH}_{4}\right)$ с реактивом Несслера и нитратный $\left(\mathrm{N}-\mathrm{NO}_{3}\right)$ с дисульфоофеноловой кислотой, подвижный фосффор $\left(\mathrm{P}_{2} \mathrm{O}_{5}\right)$ и обменный калия $\left(\mathrm{K}_{2} \mathrm{O}\right)$ по методу Чирикова. На всех вариантах опыта учли биологическую урожайность картофеля (ц/га). Провели статистическую обработку результатов этого учета с использованием программы Microsoft Excel. Оценку качества картофеля по содержанию нитратов (мг $\mathrm{NO}_{3}$ на 1 кг) в сырой массе клубней проводили экспресс-методом тканевой диагностики с помощью сухого реактива на азот и шкалы «Индам» в девятикратной повторности. Сравнивали полученные результаты с нормами оценки качества продукции по содержанию нитратов согласно ПДК (предельно допустимая концентрация), которая составляет для картофеля этих групп спелости 250 мг на кг сырой массы.

Картофрель относится к культурам интенсивного типа питания. Он предъявляет повышенные требования к почвенным факторам и условиям выращивания: влажности почвы, ее плот- ности сложения, реакции среды, агрофизическим свойствам, комплексу питательных веществ, фитосанитарной обстановке и т.д. [1215]. В то же время при высокой урожайности картофрель является хорошим предшественником, оставляя после себя достаточно большое количество легкоминерализуемого органического вещества [16].

Картофель Адретта относится к сортам столового назначения со среднеранним периодом созревания урожая. Обладает мякотью клубней желтого цвета, отличными вкусовыми качествами. Современная селекция выводит много разнообразных сортов картофреля, которые дают большие урожаи в производстве, отличаются высокими вкусовыми качествами, устойчивостью к болезням и вредителям, однако сорт Адретта по-прежнему востребован садоводамилюбителями.

Картофель Арамис является среднеспелым сортом столового назначения, отличается повышенной засухоустойчивостью, отзывчив на органические и минеральные удобрения. Мякоть светло-желтая, вкус отличный. Характеризуется высокой товарностью, хорошей лежкостью клубней при хранении, устойчивостью к возбудителям и болезням.

В состав изучаемого ОМУ входят минеральные удобрения: одинарное азотное (сернокислый аммоний), калийное (хлористый калий) и двойное комплексное азотно-фросфорное удобрение (аммофрос). Содержание азота составляет 6,5\%, фоссрора 6,5\% и калия 4,9\%. Элементы присутствуют в хорошо усвояемой подвижной форме. Минералогическая основа удобрений в виде глинистого минерала вермикулита позволяет хорошо адсорбировать элементы питания и пролонгировать их действие. Органическую основу составляет торф, который характеризуется высокой влагоемкостью, приводит к разбуханию гранул, оптимизации структуры и порозности почвы, а также к притягиванию и удержанию влаги. Удобрение отличается хорошими технологическими свойствами за счет выровненного гранулометрического физического состояния, хорошей сыпучести, слабой гигроскопичности при хранении. Оно может вноситься любыми способами, то есть как локально, так и вразброс.

Общая агрохимическая характеристика чернозема выщелоченного хозяйства, на котором проводились опыты, представлена в таблице 1. 
Общая характеристика чернозема выщелоченного хозяйства как объекта исследования

\begin{tabular}{|c|c|c|c|c|c|}
\hline Гумус в пахотном & \multirow{2}{*}{$\begin{array}{c}\text { Мощность гумусового } \\
\text { слое, } \%\end{array}$} & \multirow{2}{*}{$\mathrm{pH}_{\mathrm{KCl}}$} & \multicolumn{3}{|c|}{ Подвижные формы, мг/кг } \\
\cline { 4 - 6 } & горизонта, см & & $\mathrm{N}^{-\mathrm{NO}_{3}}$ & $\mathrm{P}_{2} \mathrm{O}_{5}$ & $\mathrm{~K}_{2} \mathrm{O}$ \\
\hline 7,4 & $30-35$ & 6,8 & 11 & 98 & 130 \\
\hline
\end{tabular}

Эта почва высоко гумусирована. Мощность гумусового горизонта составляет около $30-35 \mathrm{~cm}$. По величине $\mathrm{pH}$ ксІ почва опытного участка характеризуется нейтральной реакцией. При благоприятных условиях нитрификации обеспеченность почвы нитратным азотом, как правило, средняя, в засушливые годы низкая, что требует внесения азотных удобрений. При содержании подвижного фосффора почва опыта относится к классу с низкой обеспеченностью этим элементом питания. Обеспеченность обменным калием высокая, что связано с тяжелым гранулометрическим составом почв объектов исследования. В целом почва опытного участка характеризуется достаточно высоким естественным плодородием.

Высокую потребность в почвенной влаге картофель предъявляет перед посадкой и в фазу цветения, очень ответственную за закладку и формирование генеративных органов (клубней). Причем содержание влаги должно быть оптимальным не только в пахотном, но и подпахотном слое почвы, что связано с развитием корневой системы картофеля. Влажность почвы в фазу цветения на всех вариантах опыта и во все годы исследований не являлась лимитирующим условием питания картофеля (табл. 2). Содержание влаги в эту фазу, как правило, было выше в подпахотном слое, чем в пахотном, где более высокое физическое испарение и интенсивный расход влаги на эвапотранспирацию. Такие условия увлажнения почвы в период вегетации картофеля, даже в засушливые годы, являются оптимальными.

\section{Влажность почвы в фазу цветения картофеля, \%}

\begin{tabular}{|c|c|c|c|c|c|c|}
\hline \multirow{3}{*}{ Вариант } & \multirow{3}{*}{ Глубина, см } & \multicolumn{2}{|c|}{ Сорт Адретта } & \multicolumn{3}{|c|}{ Сорт Арамис } \\
\hline & & \multicolumn{5}{|c|}{ Год } \\
\hline & & 2015 & 2016 & 2017 & 2018 & 2019 \\
\hline \multirow{2}{*}{ Без удобрений } & $0-20$ & 24,7 & 22,9 & 16,9 & 31,8 & 26,4 \\
\hline & $20-40$ & 23,7 & 25,7 & 20,9 & 30,0 & 28,5 \\
\hline \multirow{2}{*}{1 ц/га, посадка } & $0-20$ & 28,9 & 25,2 & 18,1 & 28,7 & 26,9 \\
\hline & $20-40$ & 23,5 & 26,0 & 21,5 & 29,0 & 31,3 \\
\hline \multirow{2}{*}{ 1,5 ц/га, посадка } & $0-20$ & 33,8 & 20,0 & 19,0 & 28,1 & 29,9 \\
\hline & $20-40$ & 26,6 & 26,1 & 19,7 & 30,4 & 33,1 \\
\hline \multirow{2}{*}{2 ц/га, посадка } & $0-20$ & 30,1 & 22,9 & 22,1 & 33,0 & 28,4 \\
\hline & $20-40$ & 27,2 & 23,9 & 19,8 & 32,7 & 32,5 \\
\hline \multirow{2}{*}{ 1ц/га, прополка } & $0-20$ & 33,0 & 26,9 & 17,3 & 20,6 & 26,3 \\
\hline & $20-40$ & 33,8 & 31,1 & 17,9 & 33,1 & 30,8 \\
\hline \multirow{2}{*}{ 1ц/га, окучивание } & $0-20$ & 33,8 & 27,7 & 18,1 & 35,9 & 28,2 \\
\hline & $20-40$ & 27,5 & 32,6 & 22,2 & 31,6 & 28,9 \\
\hline
\end{tabular}

На вариантах с применением разных норм ОМУ и внесением его разными способами влажность выше за счет разбухающих влагоемких компонентов торфа и вермикулита, входящих в удобрения, обеспечивающих более высокую водоудерживающую способность почвы.
Одним из важнейших агроэкологических условий при возделывании сельскохозяйственных культур является реакция почвы. Картофрель также требователен к реакции почвы и чувствителен к химическому составу удобрений. Лучше растет картофель при слабокислой или ней- 
тральной реакции почвы. Для чернозема выщелоченного опытов характерна нейтральная реакция, благоприятная для возделывания картофеля (табл. 3).

Не установлено существенного варьирования по годам, вариантам опыта и слоям отбора реакции почвы как по величине актуальной

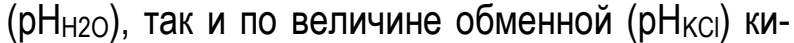
слотности. Не установлено отрицательного влияния ОМУ на реакцию чернозема выщелоченного опытного участка, что положительно характеризует новый вид удобрения по его взаимодействию с почвой и стабильности ее реакции.

Таблица 3

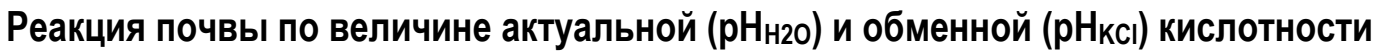
в фазу цветения картофеля

\begin{tabular}{|c|c|c|c|c|c|c|c|c|c|}
\hline \multirow{4}{*}{ Вариант } & \multirow{4}{*}{$\begin{array}{c}\text { Глубина, } \\
\text { см }\end{array}$} & \multicolumn{2}{|c|}{ Сорт Адретта } & \multicolumn{6}{|c|}{ Сорт Арамис } \\
\hline & & \multicolumn{8}{|c|}{ Год } \\
\hline & & \multicolumn{2}{|c|}{2016} & \multicolumn{2}{|c|}{2017} & \multicolumn{2}{|c|}{2018} & \multicolumn{2}{|c|}{2019} \\
\hline & & $\mathrm{pH}_{\mathrm{H} 2 \mathrm{O}}$ & $\mathrm{pH}_{\mathrm{KCl}}$ & $\mathrm{pH}_{\mathrm{H} 2 \mathrm{O}}$ & $\mathrm{pH}_{\mathrm{KCl}}$ & $\mathrm{pH}_{\mathrm{H} 2 \mathrm{O}}$ & $\mathrm{pH}_{\mathrm{KCl}}$ & $\mathrm{pH}_{\mathrm{H} 2 \mathrm{O}}$ & $\mathrm{pH}_{\mathrm{kCl}}$ \\
\hline \multirow{2}{*}{ Без удобрений } & $0-20$ & 7,2 & 6,7 & 7,1 & 6,8 & 7,7 & 7,2 & 6,9 & 6,5 \\
\hline & $20-40$ & не опр. & не опр & 7,1 & 6,8 & 7,7 & 7,4 & 7,1 & 6,5 \\
\hline \multirow{2}{*}{1 ц/га, посадка } & $0-20$ & 7,2 & 6,7 & 7,2 & 6,8 & 7,7 & 7,4 & 7,1 & 6,5 \\
\hline & $20-40$ & & & 7,1 & 6,7 & 7,7 & 7,6 & 7,2 & 6,5 \\
\hline \multirow{2}{*}{ 1,5 ц/га, посадка } & $0-20$ & 7,2 & 6,7 & 7,1 & 6,9 & 7,6 & 7,4 & 7,2 & 6,5 \\
\hline & $20-40$ & & & 7,2 & 6,6 & 7,7 & 7,6 & 7,1 & 6,5 \\
\hline \multirow{2}{*}{2 ц/га, посадка } & $0-20$ & 7,2 & 6,7 & 7,2 & 6,8 & 7,7 & 7,4 & 6,9 & 6,4 \\
\hline & $20-40$ & & & 7,1 & 6,8 & 7,7 & 7,6 & 7,1 & 6,5 \\
\hline \multirow{2}{*}{1 ц/га, прополка } & $0-20$ & 7,1 & 6,7 & 7,1 & 6,9 & 7,7 & 7,2 & 6,9 & 6,5 \\
\hline & $20-40$ & & & 7,2 & 6,9 & 7,5 & 7,3 & 7,0 & 6,4 \\
\hline \multirow{2}{*}{1 ц/га, окучивание } & $0-20$ & 7,2 & 6,7 & 7,1 & 6,7 & 7,6 & 7,4 & 7,0 & 6,5 \\
\hline & $20-40$ & & & 7,2 & 6,7 & 7,6 & 7,5 & 7,0 & 6,4 \\
\hline
\end{tabular}

Картофрель, как культура интенсивного типа питания, предъявляет повышенные требования к обеспеченности питательными веществами. При внесении удобрения под картофель сорта Адретта в годы проведения опытов установлена заметная оптимизация агрохимических показателей. При этом обеспеченность основными элементами питания переходит из класса низкой в более высокий. Установлена повышенная обеспеченность аммонийным азотом, высокая обеспеченность подвижным фоосфором и очень высокая обменным калием.

В таблице 4 представлены результаты почвенной диагностики условий питания картофреля сорта Арамис. В фразу цветения картофеля содержание нитратного азота в почве резко снижается за счет интенсивного выноса этого элемента на формирование ботвы, а также снижения активности текущей нитрификации при де- фиците почвенной влаги, который был связан с засушливым июнем 2017 г. Однако обеспеченность аммонийным азотом остается высокой, что, несмотря на интенсивный вынос азота, обеспечивает оптимальное азотное питание картофреля. Увеличение нормы внесения ОМУ при посадке картофреля и внесение этого удобрения в подкормку несколько увеличивали содержание нитратного азота по сравнению с контролем. Количество подвижного фоссрора снижалось, что связано с усилением его выноса растениями. Четкой закономерности изменения содержания обменного калия по вариантам опыта от посадки до цветения не установлено. Этот элемент интенсивнее используется картофелем во вторую половину вегетации. При внесении ОМУ в подпахотном слое обеспеченность питательными веществами в ряде случаев выше за счет лучшей влагообеспеченности. 
Содержание основных элементов питания в почве в фразу цветения картофеля сорта Арамис, мг/ кг почвы

\begin{tabular}{|c|c|c|c|c|c|c|c|c|c|c|c|c|c|}
\hline \multirow[b]{2}{*}{ Вариант } & \multirow{2}{*}{$\begin{array}{c}\text { Глуби- } \\
\text { на, } \\
\text { см }\end{array}$} & \multicolumn{4}{|c|}{2017 г. } & \multicolumn{4}{|c|}{2018 г. } & \multicolumn{4}{|c|}{2019 г. } \\
\hline & & $\mathrm{N}-\mathrm{NH}_{4}$ & $\begin{array}{c}\mathrm{N}- \\
\mathrm{NO}_{3}\end{array}$ & $\mathrm{P}_{2} \mathrm{O}_{5}$ & $\mathrm{~K}_{2} \mathrm{O}$ & $\begin{array}{c}\mathrm{N}- \\
\mathrm{NH}_{4}\end{array}$ & $\mathrm{~N}-\mathrm{NO}_{3}$ & $\mathrm{P}_{2} \mathrm{O}_{5}$ & $\mathrm{~K}_{2} \mathrm{O}$ & $\mathrm{N}-\mathrm{NH}_{4}$ & $\mathrm{~N}-\mathrm{NO}_{3}$ & $\mathrm{P}_{2} \mathrm{O}_{5}$ & $\mathrm{~K}_{2} \mathrm{O}$ \\
\hline \multirow{2}{*}{$\begin{array}{l}\text { Без } \\
\text { удобрений }\end{array}$} & $0-20$ & 26,5 & 2,6 & 213 & 126 & 4,3 & 26,0 & 265 & 445 & 4,2 & 13,9 & 293 & 403 \\
\hline & $20-40$ & 28,5 & 4,2 & 171 & 114 & 5,0 & 29,0 & 419 & 352 & 4,6 & 11,1 & 246 & 335 \\
\hline \multirow{2}{*}{$\begin{array}{l}1 \text { ц/га, } \\
\text { посадка }\end{array}$} & $0-20$ & 23,6 & 3,3 & 176 & 114 & 4,3 & 22,0 & 248 & 320 & 3,4 & 10,5 & 285 & 507 \\
\hline & $20-40$ & 24,2 & 4,8 & 179 & 127 & 3,7 & 25,0 & 252 & 394 & 3,9 & 7,0 & 236 & 309 \\
\hline \multirow{2}{*}{$\begin{array}{l}\text { 1,5 ц/га, } \\
\text { посадка }\end{array}$} & $0-20$ & 35,1 & 5,6 & 215 & 269 & 4,8 & 14,0 & 144 & 342 & 4,1 & 11,7 & 428 & 531 \\
\hline & $20-40$ & 40,1 & 3,9 & 183 & 106 & 5,1 & 20,0 & 289 & 410 & 3,8 & 13,1 & 343 & 429 \\
\hline \multirow{2}{*}{$\begin{array}{l}2 \text { ц/га, } \\
\text { посадка }\end{array}$} & $0-20$ & 28,9 & 5,3 & 178 & 111 & 4,3 & 18,0 & 160 & 348 & 3,9 & 15,8 & 416 & 506 \\
\hline & $20-40$ & 24,5 & 5,3 & 174 & 112 & 5,1 & 21,0 & 172 & 520 & 3,6 & 12,3 & 359 & 504 \\
\hline \multirow{2}{*}{$\begin{array}{l}\text { ц/га, } \\
\text { прополка }\end{array}$} & $0-20$ & 27,2 & 5,0 & 209 & 122 & 5,3 & 26,0 & 405 & 307 & 3,6 & 11,3 & 385 & 441 \\
\hline & $20-40$ & 34,5 & 5,3 & 218 & 127 & 5,7 & 24,0 & 22 & 290 & 11,1 & 8,5 & 263 & 335 \\
\hline \multirow{2}{*}{$\begin{array}{l}1 \text { ц/га, } \\
\text { окучивание }\end{array}$} & $0-20$ & 28,6 & 5,4 & 207 & 93 & 4,2 & 23,0 & 22,0 & 526 & 3,6 & 14,5 & 319 & 501 \\
\hline & $20-40$ & 32,0 & 3,7 & 218 & 186 & 5,8 & 20,0 & 22,5 & 370 & 3,2 & 11,1 & 237 & 435 \\
\hline
\end{tabular}

В 2018 г. зафиксировано резкое снижение содержания аммонийной формы и увеличение нитратного азота в течение вегетации, что связано с активным включением аммония в процессы нитрификации за счет выпавших осадков, повышения влажности почвы и оптимальной температурой перед цветением картофеля. По сумме нитратного и аммонийного азота обеспеченность почвы оптимальная.

В 2019 г. внесение ОМУ привело к заметной оптимизации агрохимических показателей почвы. Увеличилось суммарное содержание минеральных форм азота от низкой до средней и повышенной степени обеспеченности. Характерно очень высокое содержание подвижного фосфора и обменного калия как за счет внесения удобрений, так и за счет естественного почвенного плодородия.

В целом для условий Назаровской лесостепи уровень урожайности картофеля сорта Адретта и сорта Арамис достаточно высокий, особенно в благоприятные по погодным условиям годы (2015, 2017, 2019).

Практически на всех вариантах опыта по сравнению с контролем урожайность картофеля сорта Адретта в 2015 г. выше, что подтверждается статистически. В 2016 г. уровень урожай- ности картофеля сорта Адретта был существенно ниже на всех вариантах опыта. Получены статистически недостоверные прибавки урожайности картофеля этого сорта (табл. 5).

При внесении повышенных норм ОМУ урожайность картофреля в 2016 г. ниже, чем на контроле, что связано с засушливой погодой в июне и возможным токсическим эффректом от этих норм при прорастании клубней картофеля. Острый дефицит влаги в период клубнеобразования также отрицательно повлиял на величину урожайности картофеля. Уровень урожайности картофеля сорта Арамис значительно выше, чем сорта Адретта. Несмотря на то что погодные условия начала вегетационного периода 2017 г. были засушливые, а вторая половина вегетации дождливая и холодная, этот сорт оказался более продуктивным по сравнению с сортом Адретта. В 2017 г. самую большую статистически достоверную прибавку урожайности показывают варианты при внесении ОМУ в дозах 1 и 1,5 ц/га. В 2018 г. при внесении 1,5 и 2 ц/га ОМУ урожайность картофеля почти такая же, как на контроле, что также связано с угнетающим воздействием повышенной нормы удобрения. 
Урожайность картофеля (ц/га) и содержание нитратов в клубнях

Таблица 5 (мг/кг сырой массы при ПДК 250)

\begin{tabular}{|c|c|c|c|c|c|c|c|c|c|c|}
\hline \multirow{3}{*}{ Вариант } & \multicolumn{4}{|c|}{ Сорт Адретта } & \multicolumn{6}{|c|}{ Сорт Арамис } \\
\hline & \multicolumn{2}{|c|}{2015 г. } & \multicolumn{2}{|c|}{2016 г. } & \multicolumn{2}{|c|}{2017 г. } & \multicolumn{2}{|c|}{2018 г. } & \multicolumn{2}{|c|}{2019 г. } \\
\hline & ц/га & $\mathrm{M \Gamma} / \mathrm{K} \Gamma$ & ц/га & $\mathrm{M \Gamma} / \mathrm{K} \Gamma$ & ц/га & $\mathrm{M \Gamma} / \mathrm{KL}$ & ц/га & $\mathrm{Mr} / \mathrm{K \Gamma}$ & ц/га & $\mathrm{Mr} / \mathrm{K \Gamma}$ \\
\hline Контроль & 308,6 & 47,6 & 240,0 & 42 & 303,3 & 124 & 176,0 & 94 & 206,0 & 111 \\
\hline $\begin{array}{l}1 \text { ц/га, } \\
\text { посадка }\end{array}$ & 358,0 & 83 & 258,3 & 47 & 420,0 & 138 & 191,0 & 100 & 224,0 & 110 \\
\hline $\begin{array}{l}\text { 1,5 ц/га, } \\
\text { посадка }\end{array}$ & 345,7 & 56 & 211,6 & 42 & 419,3 & 142 & 178,0 & 98 & 212,0 & 117 \\
\hline $\begin{array}{l}2 \text { ц/га, } \\
\text { посадка }\end{array}$ & 358,0 & 98 & 211,6 & 70 & 315,3 & 125 & 177,0 & 92 & 221,0 & 115 \\
\hline $\begin{array}{l}\text { 1ц/га, } \\
\text { прополка }\end{array}$ & 469,1 & 41 & 163,3 & 44 & 201,0 & 132 & 145,0 & 99 & 253,0 & 114 \\
\hline $\begin{array}{l}\text { 1ц/га, } \\
\text { окучивание }\end{array}$ & 493,8 & 67 & 195,0 & 50 & 206,7 & 124 & 164,0 & 94 & 251,0 & 112 \\
\hline $\mathrm{HCP}_{05}$ & 34,8 & & 107,8 & & 97,8 & & 14,7 & & 45,0 & \\
\hline
\end{tabular}

Максимальная статистически достоверная прибавка урожайности клубней картофеля сорта Арамис получена при внесении ОМУ в норме 1,0 ц/га при посадке. Внесение удобрения в подкормку снизило урожайность картофеля, что также связано с засушливой погодой в июне, и как следствие, с отрицательным влиянием дефицита влаги в период клубнеобразования. В 2019 г. максимальная прибавка урожайности установлена на варианте с внесением ОМУ в норме 1 ц/га при подкормке во время вегетации. Это обусловлено лучшими условиями увлажнения почвы атмосферными осадками в период между интенсивным нарастанием ботвы и цветением. Увеличение нормы ОМУ до 2 ц/га существенно не повысило урожайность картофеля по сравнению с контрольным вариантом, повидимому, за счет угнетающего действия хлора, который в составе хлористого калия входит в это органо-минеральное удобрение.

Содержание нитратов в сырой массе клубней картофеля сорта Адретта на всех вариантах опыта не превышает предельно допустимую концентрацию (ПДК). При внесении ОМУ и увеличении нормы удобрения отмечается незначительное увеличение нитратов в соке клубней картофеля, однако оно также ниже ПДК. Сорт картофеля Арамис показал способность к более высокой кумуляции нитратов. Во все сроки определения их содержание в сырой массе клубней картофеля этого сорта было существенно выше, чем у сорта Адретта, однако не превы- шало предельно допустимую концентрацию. При внесении под картофель сорта Арамис разных норм ОМУ и различными способами получена экологически чистая продукция, содержащая нитраты существенно ниже ПДК.

Заключение. Установлена оптимизация условий питания картофеля при внесении ОМУ по всем показателям почвенной диагностики. Характерно повышение влажности почвы за счет влагоемкого органического компонента торфа и хорошо разбухающего минерала вермикулита, входящих в состав ОМУ. Внесение ОМУ стабилизирует реакцию почвы, улучшает условия питания. В засушливые годы при внесении повышенных норм ОМУ зафиксировано токсическое влияние, приводящее к снижению урожайности обоих сортов картофеля, особенно сорта Адретта. В оптимальные по погодным условиям годы получена достаточно высокая урожайность картофреля.

На всех вариантах опыта и во все годы исследований содержание нитратов в клубнях картофеля сорта Адретта и сорта Арамис не превышало предельно допустимую концентрацию.

Таким образом, за счет сбалансированного содержания питательных элементов в изучаемом комплексном органо-минеральном удобрении, регулирующем и оптимизирующем условия многоэлементного питания, получена экологически чистая продукция картофеля при достаточно высоких уровнях урожайности в многолетнем цикле проведения опытов. 


\section{Литература}

1. Мингалев С.К. Реакция сортов картофеля на разные виды удобрений // Аграрный вестник Урала. 2014. № 7. С. 74-77.

2. Солоничкин В.Н. Оптимизация минерального питания картофеля // Картофельная система. 2010. № 4. С. 20-22.

3. Денисова А.Д., Петровский А.С. Специальные удобрения. Щелково: $\mathrm{AO}$ «Щелково Агрохим», 2018. 132 c.

4. Инновационные комплексные органоминеральные удобрения. Doktor Farmer. 2018. 59 c. URL: doctorfarmer.ru/ ru/product/65/.

5. Сорокина О.А. Состояние химизации земледелия на примере применения удобрений в Российской Федерации и Красноярском крае // Вестник КрасГАУ. 2015. № 9. C. 9-17.

6. Сорокина О.А., Зимогляд М.В. Влияние нового органо-минерального удобрения на условия питания и урожайность картофреля // Вестник КрасГАУ. 2019. № 7. С. 43-50.

7. Логинов Ю.П., Казак А.А. Рекомендации по выращиванию картофеля в ЛПХ Тюменской области. Тюмень, 2017. 116 с.

8. Логинов Ю.П., Казак А.А., Якубышина Л.И. Картофелеводство Сибири - надежный резерв продовольственной безопасности страны // Инновации в технологиях возделывания сельскохозяйственных культур: мат-лы Всерос. науч.-практ. конфр. 2017. С. 192-197.

9. Андрианов А.Д., Андрианов Д.А. Биопрепараты на раннем картофеле // Картофелеводство: сб. науч. тр. Минск, 2017. Т. 25. C. $105-115$.

10. Бутов А.В., Адоньев С.О. Регуляторы роста на картофеле // Картофель и овощи. 2015. № 5. C. 29-30.

11. Stupnitsky D.N., Pantyukhov I.V., Bobojonov A.A., Giyosov N.K. and A.A. Pulotov. Dynamics of formation of yield of seed potatoes applying humic drugs. Krasnoyarsk State Agrarian University, Krasnoyarsk, Russia AGRITECH-II-2019 IOP Conf. Series: Earth and Environmental Science (2020) 421 062024.

12. Гастило Д.С., Турко С.А. Влияние обработки почвы и агрофизических показателей на урожайность картофреля // Картофрелеводство: сб. науч. тр. Минск, 2017. Т. 25. C. 187-195.

13. Казак А.А., Логинов Ю.П., Сидоров П.Т. Выращивание экологически чистого картофеля в лесостепной зоне Тюменской области // Вестник Курганской ГСХА. 2018. № 1. С. 31-34.

14. Халипский АН., Чураков А.А., Ступницкий Д.Н. [и др.]. Влияние фона питания, рельефра местности на урожайность и распространение болезней картофеля // Достижения науки и техники АПК. 2017. Т 31. № 8. C. 31-34.

15. Халипский А.Н. Роль экотипа сорта и условий выращивания в эффрективности сортосмены картофеля в Красноярском крае // Вестник КрасГАУ. 2008. № 3. С. 130-136.

16. Vlasenko, O.A., Khalipsky A.N., Stupnitsky D.N. Vegetable structure balance in agrochernozems and the quality of seed production in the field crops cultivation with elements of soil protective technologies // IOP Conference Series: Earth and Environmental Science. 2019. 315(4). C. 05204.

\section{Literatura}

1. Mingalev S.K. Reakcija sortov kartofelja na raznye vidy udobrenij // Agrarnyj vestnik Urala. 2014. № 7. S. 74-77.

2. Solonichkin V.N. Optimizacija mineral'nogo pitanija kartofelja // Kartofel'naja sistema. 2010. № 4. S. 20-22.

3. Denisova A.D., Petrovskij A.S. Special'nye udobrenija. Shhelkovo: AO «Shhelkovo Agrohim», 2018. $132 \mathrm{~s}$.

4. Innovacionnye kompleksnye organomineral'nye udobrenija. Doktor Farmer. 2018. 59 s. URL: doctorfarmer.ru/ru/product/65/.

5. Sorokina O.A. Sostojanie himizacii zemledelija na primere primenenija udobrenij v Rossijskoj Federacii i Krasnojarskom krae // Vestnik KrasGAU. 2015. № 9. S. 9-17.

6. Sorokina O.A., Zimogljad M.V. Vlijanie novogo organo-mineral'nogo udobrenija na uslovija pitanija i urozhajnost' kartofelja // Vestnik KrasGAU. 2019. № 7. S. 43-50. 
7. Loginov Ju.P., Kazak A.A. Rekomendacii po vyrashhivaniju kartofelja $v$ LPH Tjumenskoj oblasti. Tjumen', 2017. $116 \mathrm{~s}$.

8. Loginov Ju.P., Kazak A.A., Jakubyshina L.I. Kartofelevodstvo Sibiri - nadezhnyj rezerv prodovol'stvennoj bezopasnosti strany /I Innovacii $v$ tehnologijah vozdelyvanija sel'skohozjajstvennyh kul'tur: mat-ly Vseros. nauch.-prakt. konf. 2017. S. 192-197.

9. Andrianov A.D., Andrianov D.A. Biopreparaty na rannem kartofele // Kartofelevodstvo: sb. nauch. tr. Minsk, 2017. T. 25. S. 105-115.

10. Butov A.V., Adon'ev S.O. Reguljatory rosta na kartofele // Kartofel' i ovoshhi. 2015. № 5. S. 29-30.

11. Stupnitsky D.N., Pantyukhov I.V., Bobojonov A.A., Giyosov N.K. and A.A. Pulotov. Dynamics of formation of yield of seed potatoes applying humic drugs. Krasnoyarsk State Agrarian University, Krasnoyarsk, Russia AGRITECH-II-2019 IOP Conf. Series: Earth and Environmental Science (2020) 421 062024.

12. Gastilo D.S., Turko S.A. Vlijanie obrabotki pochvy i agrofizicheskih pokazatelej na urozhajnost' kartofelja // Kartofelevodstvo: sb. nauch. tr. Minsk, 2017. T. 25. S. 187-195.

13. Kazak A.A., Loginov Ju.P., Sidorov P.T. Vyrashhivanie jekologicheski chistogo kartofelja $\mathrm{V}$ lesostepnoj zone Tjumenskoj oblasti // Vestnik Kurganskoj GSHA. 2018. № 1. S. 31-34.

14. Halipskij AN., Churakov A.A., Stupnickij D.N. [i dr.]. Vlijanie fona pitanija, rel'efa mestnosti na urozhajnost' i rasprostranenie boleznej kartofelja // Dostizhenija nauki i tehniki APK. 2017. T 31. № 8. S. 31-34.

15. Halipskij A.N. Rol' jekotipa sorta i uslovij vyrashhivanija $\mathrm{v}$ jeffektivnosti sortosmeny kartofelja v Krasnojarskom krae // Vestnik KrasGAU. 2008. № 3. S. 130-136.

16. Vlasenko, O.A., Khalipsky A.N., Stupnitsky $D . N$. Vegetable structure balance in agrochernozems and the quality of seed production in the field crops cultivation with elements of soil protective technologies // IOP Conference Series: Earth and Environmental Science. 2019. 315(4). S. 05204. 